\title{
Dictynna
}

Dictynna

Revue de poétique latine

18 | 2021

Varia

\section{Catullus in Late Imperial Greek Literature: the Case of Philostratus}

\section{Flora Iff-Noël}

\section{(2) OpenEdition \\ 12 Journals}

\section{Electronic version}

URL: https://journals.openedition.org/dictynna/2655

DOI: 10.4000/dictynna.2655

ISSN: $1765-3142$

\section{Publisher}

Université de Lille

\section{Electronic reference}

Flora Iff-Noël, "Catullus in Late Imperial Greek Literature: the Case of Philostratus", Dictynna [Online], 18 | 2021, Online since 01 December 2021, connection on 19 December 2021. URL: http:// journals.openedition.org/dictynna/2655 ; DOI: https://doi.org/10.4000/dictynna.2655

This text was automatically generated on 19 December 2021.

\section{(c) (i) (9)}

Les contenus des la revue Dictynna sont mis à disposition selon les termes de la Licence Creative Commons Attribution - Pas d'Utilisation Commerciale - Pas de Modification 4.0 International. 


\title{
Catullus in Late Imperial Greek Literature: the Case of Philostratus
}

\author{
Flora Iff-Noël
}

1 The Imagines by Philostratus at the turn of the second and third centuries as well as the Ekphraseis by Callistratus in the third or fourth century CE are characterized by their illusionist vision of art. Page after page, the artworks' quality is measured according to their capacity to seem about to speak, move or become alive. This extreme mimesis which leads to a confusion between art and nature appears frequently in ancient texts, but it is mainly in Hellenistic ekphrastic epigrams that it came to constitute a fullfledged topos, structured around defining characteristics. ${ }^{1}$ Here is an example of uncertain date by Glaucus of Athens, about the Bacchante statue by Skopas (Anth. Pal. 9.7742):

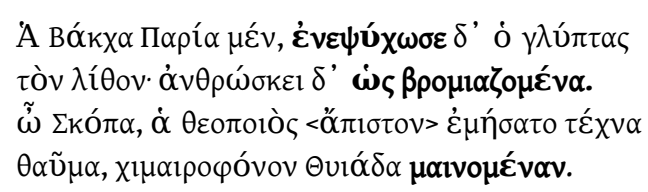

The Bacchante is in Parian marble, but the sculptor has given life to the stone: she springs forth, as if she were possessed by Bromius.

O Scopas, your god-creating art has produced an incredible

wonder, a goat-hunting Thyad, full of frenzy.

2 The topos consists in praising the sculptor and his work because of the latter's illusion of movement ( $\dot{\alpha} v \theta \rho \omega ́ \sigma \kappa \omega ~ 1.1$, "to spring forth") and of life (the verb $\dot{\varepsilon} \mu \psi v x o ́ \omega ~ 1.1$, "to give life, to animate," is developed by the growing Bacchic raving 1.2-4, first only

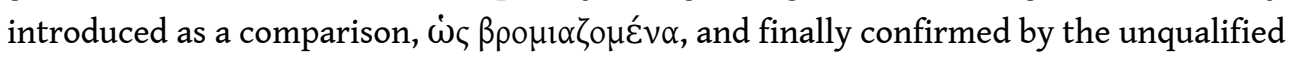
participle $\mu \alpha \imath v o \mu \varepsilon ́ v \alpha v)$.

3 Some artworks even speak out in the first person, ${ }^{3}$ giving a new meaning to the Ichrede, an archaic convention of funerary and votive epigrams. Philostratus himself uses indirect speech to paraphrase Polyphemus (2.18), the Andrians (1.25.2) and some unidentified singers (2.11), but he also makes an Apollo painting speak out to lament Hermes's theft for thirty words quoted in oratio recta (1.26.4). Philostratus seems to 
decline all of the topos's possible variations, as analyzed by Ruth Webb ${ }^{4}$ in the case of Menoeceus's blood (1.4) that seems to bleed out of the painting, or as commented by Zahra Newby ${ }^{5}$ in the case of the narrator's addresses to hunters (1.28) and to Narcissus (1.3) as if they were real interlocutors.

4 However, Ariadne's painting (1.15) stands out for its lack of illusionism. Ariadne is represented so sound asleep that she seems neither to speak, move nor even be alive: she appears completely passive. This characterization is particularly striking for the Catullan reader who remembers one of the most famous and most rewritten Latin poems, carmen 64. As is well-known, this poem's narration of Peleus and Thetis's wedding is interrupted by the description of the coverlet placed on their wedding bed which represents Ariadne, forsaken by Theseus on the island of Dia. This woven Ariadne appears so alive that she speaks out for 69 lines. Although scholars have mostly interpreted the innovations in Catullus's ekphrasis as a return to epic narration or to drama, I have shown that, far from disregarding the artwork from which it emanates, Ariadne's direct speech attempts to maximize the ekphrasis and to allow its reader not only to see but to hear the artwork, following the illusionist topos of Hellenistic ekphrastic epigram. ${ }^{6}$

Would it be possible to read the surprising lack of illusionism in Philostratus's Ariadne as a correction of Catullus's extraordinarily illusionistic Ariadne? Could Philostratus stage the Atticist's apparent rejection of Latin literature by silencing the Catullan Ariadne and by making her neoteric and even proto-elegiac love song disappear? I am personnaly convinced that Philostratus not only read Catullus and other Latin authors but also alluded to them; yet, in the absence of indisputable evidence, I hope to at least show that his Roman readers would draw a parallel between Philostratus's mute Ariadne and Catullus's speaking one. ${ }^{7}$

6 Before starting a close reading of Philostratus and Catullus, let us summarize the state of the art on possible Roman influences on Greek literature on the one hand, and the importance of Catullus from the second to the fourth century CE on the other hand. While the Atticism of imperial Greek literature has caused the exclusion of references not only to Roman literature but also to contemporary Greek writers, new scholarship is slowly investigating bilingualism and exchanges between Greek and Roman literature. The work of reference by Rochette (1997) on Latin in the Greek world showed that bilingualism was a rule for the elites ${ }^{8}$, and especially among Greeks living in Rome, which was the case of Philostratus'. Lucian's allusions to Roman literature have been investigated thoroughly by e.g. Bozia (2015). Claudius Aelian, a Roman who wrote in Greek and does not name any Roman models, has been shown by Smith (2014) to allude to Vergil's Aeneid and Ovid's Metamorphoses. Jolowicz (2021) has just published his research on the presence of Latin poetry in the Greek novels. Virgil in particular, but also Ovid emerge as well-known to Greek writers ${ }^{10}$. In the case of Philostratus's Imagines, Bryson ${ }^{11}$ and MacDonald (forthcoming) convincingly show echoes of Ovid's Metamorphoses.

\section{Catullus's reception from the second to the fourth century CE}

7 What was the status of Catullus from the second to the fourth century CE? Julia Gaisser asserts that "Catullus greatly influenced both the Augustan poets and Martial, but his 
poems had fallen out of fashion by the end of the second century." ${ }^{12}$ However, I have found 13 authors who mention him or quote him in Latin. They came from very different areas of the Empire (from Rome, to Gaul and Africa), included pagans and Christians, and wrote in all sorts of genres. The most famous are Apuleius, Gellius, Ausonius, Servius, Jerome, Augustine, Macrobius and Martianus Capella. ${ }^{13}$ Four inscriptions also refer to Catullus. ${ }^{14}$ Moreschini asserts that the Peruigilium Veneris betrays Catullan influences; ${ }^{15}$ Hallett and Hindermann claim that Petronius also engages with Catullus. ${ }^{16}$

8 The anecdote told by Gellius (NA 19.9) is revealing: some Greeks living in Rome in the second century CE are said to know Latin literature (nostras quoque litteras haud incuriose docti). They state that Greek literature is superior to Latin literature, and that Anacreon was rivaled by none except by a few lines of Catullus and Calvus (saepeque eum percontabantur quid de Anacreonte ceterisque id genus poetis sentiret et ecquis nostrorum poetarum tam fluentes carminum delicias fecisset. "Nisi Catullus," inquiunt, "forte pauca et Caluus itidem pauca"). They go on to criticize Laevius, Hortensius, Cinna and Memmius. Thus, Catullus was at least relatively famous at the time. Jolowicz also notes that these "Greeks [were] well versed enough in Latin literature to be able to detect stylistic differences between Catullus and Calvus [...], and Laevius, Hortenius, Cinna, and Memmius". ${ }^{17}$

9 Do we have any trace of Catullus in Greek? Hose (1994) argues that the Greek erotic elegies contained in the second century P.Oxy. 3723 (= SSH 1187) actually date from the imperial period and were largely influenced by Latin elegy, which itself owes much to Catullus. Hodkinson (2009) shows that Philostratus's submissive epistolary persona may have been inspired by Latin elegy. Wiseman (1986: 118) alludes to some of the thematic correspondences between Catullus and the Greek novels. In particular, Jolowicz (2021: 128) argues that Achilles Tatius's language is endebted to Catullus, Virgil, Propertius and Tibullus. For example, he considers that Achilles 1.8.9 alludes to Catullus 11 (and, to a lesser extent, to Catullus 62.39-47) via Virgil, Aen. 9.435 (Jolowicz: 141-142). Schoess $(2018)^{18}$ argues that Alciphron's Letters of Courtesans 4.19 alludes to Catullus's and Ovid's Ariadne, and considers that the readers would have noticed it. ${ }^{19}$ Gleason says that a poem composed in Greek by Marcellus of Side in the second century and inscribed at Marathon by Herodes Atticus for his wife alludes to Catullus 68 (SEG 23.121). ${ }^{20}$ Thus, Catullus seems to have remained familiar to Latin speakers and to have influenced some Greek texts as well.

10 In particular, no extant treatment of Ariadne's myth equals Catullus's, except its numerous rewritings by $\mathrm{Ovid}^{21}$, as well as Plutarch's Life of Theseus. Ariadne only appears briefly in the Iliadic ekphrasis of Achilles's shield (18.590-605). However, Philostratus could have been inspired by lost tragedies on the topic such as Euripides's Theseus, and -rather less probably-Sophocles' Aegeus.

11 Philostratus's Atticism should not make us disregard his extreme erudition and his life in Rome at the imperial court. As shown by Basil Duffalo, Philostratus seems far from ignoring Romanity, rather he deliberately omits any reference to it: "the Eikones stages ecphrasis as a didactic performance by a Greek for Greeks-and this in an Italian city, Naples, described simply as home to men of 'the Greek race,' who, as 'people of

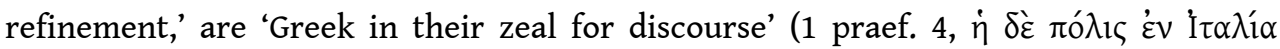

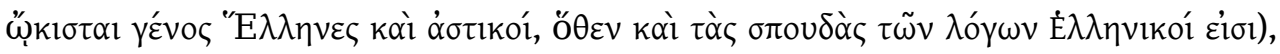
as though the city's population had remained essentially unchanged since its days as a 
Greek colony."22 To the Latinist, that sounds like a provocation: Naples, a Greek town in the third century CE? ${ }^{23}$ Will Hellenists even dispossess us of Pompeii and Herculaneum? Now that we have shown that Philostratus could have known Catullus without explicitly quoting him, let us consider the details of Ariadne's treatment.

\section{Catullus's Bacchic Ariadne and the Bacchantes of Philostratus and Callistratus}

From the very beginning of poem 64's ekphrasis, Catullus's Ariadne is represented awake and full of life:

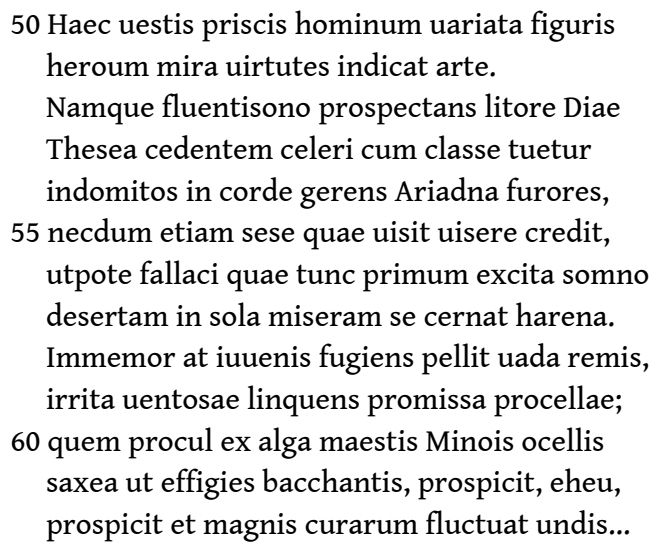

This textile, adorned with the figures of men of old, illustrates the deeds of heroes with wondrous art. Indeed, gazing from the wave-sounding shore of Dia, she perceives Theseus fleeing aboard his swift ship, Ariadne whose heart holds untamed passions, and she cannot even believe yet that she sees what she sees, since, barely awoken from a deceitful sleep, she discovers herself to have been forsaken on the lonely sand. Meanwhile the forgetful youth flees and strikes the waters with his oars, leaving his empty promises to the gusty storm, he whom, from the seaweed, with sad eyes, Minois's daughter, like a stone statue of a Bacchante, watches, alas, watches, and is tossed on a sea of torment...

The first mention of Ariadne's name 1.54 is surrounded by her "untamed passions" (indomitos in corde gerens Ariadna furores) making the reader plunge into her "heart"'s inner feelings. After her emotions, Catullus mentions her thoughts through the verb credit 1.55 ("she believes"). Catullus alludes here to a well-known debate from art criticism, i.e. the representation of ethos ("character") and pathos ("emotions"). The point is to oppose Socrates' claim that art cannot represent what matters most, "the soul's character." ${ }^{24}$

Throughout this initial description, the focus of attention is Ariadne's gaze (depicted by no less than seven verbs of vision in eleven lines) because the eyes were considered to express inner feelings: Ariadne has "sad eyes" (maestis ocellis 1.60). Indeed, the eyes were key for illusionist sculptures, as shown by the ivory, metal or glass inlays used to make them shine and make the statue seem alive. ${ }^{25}$ It is these sad eyes that introduce the comparison of the woven Ariadne to a Bacchante statue, effigies, 1.61. This Bacchante statue probably alludes to that sculpted by Skopas in the fourth century BCE, 
${ }^{26}$ and especially to the many epigrams such as Glaucus's quoted above that praised the illusion of life produced by the statue's attitude of Bacchic frenzy.

Let us compare the passage to Philostratus's description of a Bacchic painting (Imagines

1.18) and to Callistratus's description of the Bacchante statue by Skopas (Ekphraseis 2):

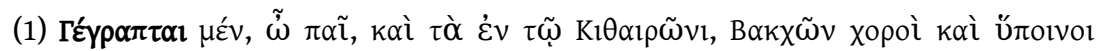

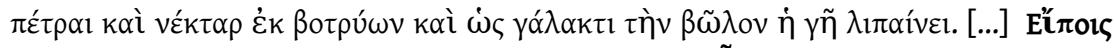

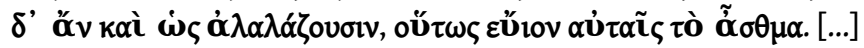

(3) [...] 'A

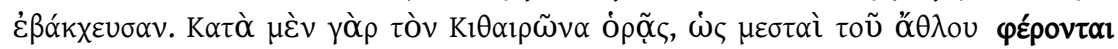

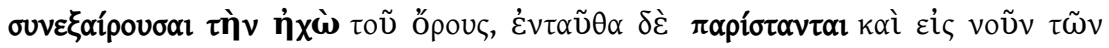

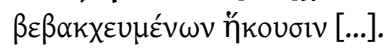

Here are also painted, my boy, scenes from Mount Cithaeron-choruses of Bacchantes, and rocks flowing with wine, and nectar dripping from clusters of grapes, and the earth enriching the broken soil with milk. [...] You would even say they were raising the shout of victory, so like the Bacchic cry is their panting. [...] (3) [...] Not only their madness has left them, but also the strength they possessed in the Bacchic revel. On Cithaeron you see how, inspired by the conflict, they rush headlong, rousing the echoes on the mountain side, but here they stand still and have come to a realization of what they did in their revels.

Philostratus, Imagines 1.18, 1-3.

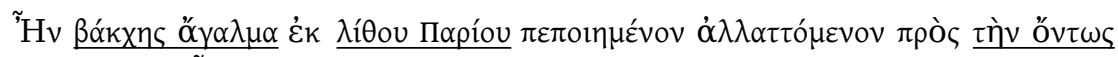

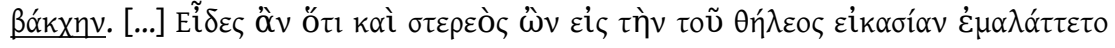

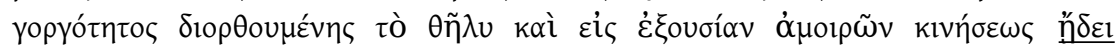

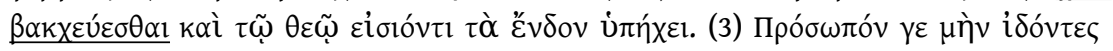

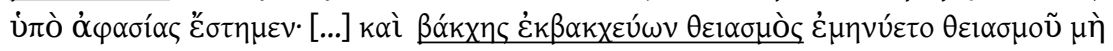

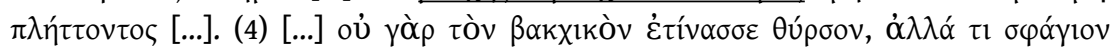

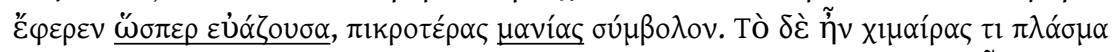

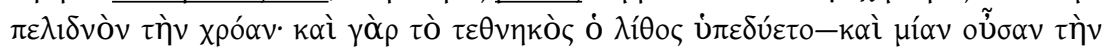

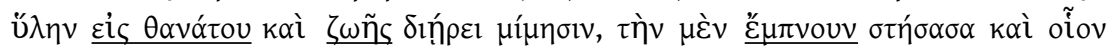

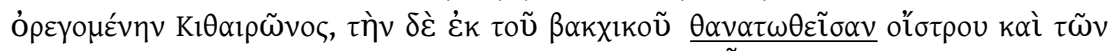

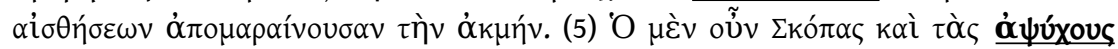
$\varepsilon i \delta \omega \lambda$ ก

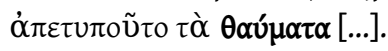

A statue of a Bacchante, wrought from Parian marble, has been transformed into a real Bacchante. [...] You might have seen that, hard though it was, it became soft to the semblance of the feminine, its vigour, however, correcting the femininity, and that, though it had no power to move, it knew how to leap in Bacchic dance and would respond to the god when he entered into its inner being. (3) When we saw the face we stood speechless; [...] so clear an intimation was given of a Bacchante's divine possession stirring Bacchic frenzy though no such possession aroused it [...]. (4) [...] For it was not waving the Bacchic thyrsus, but it carried a victim as if it were uttering the Evian cry, the token of a more poignant madness; and the figure of the kid was livid in colour, for the stone assumed the appearance of dead flesh; and though the material was one and the same it severally imitated life and death, for it made one part instinct with life and as though eager for the Cithaeron, and another part brought to death by Bacchic frenzy, its keen senses withered away. (5) Thus Scopas fashioning creatures without life was an artificer of truth and imprinted miracles on bodies made of inanimate matter.

Callistratus, Ekphraseis, 2.2-5, Bacchante statue by Skopas. 
Catullus, Philostratus and Callistratus all draw on the illusionist epigrammatic topos, as shown by the table below:

\begin{tabular}{|c|c|c|c|}
\hline Catullus & Glaucus & Philostratus & Callistratus \\
\hline $\begin{array}{l}1.61 \text { saxea } \quad[. . .] \quad \text { effigies } \\
\text { bacchantis }\end{array}$ & $\begin{array}{l}1.1 \quad \text { A } \quad \text { Bók } \kappa \alpha \alpha \\
\Pi \alpha \rho i ́ \alpha\end{array}$ & 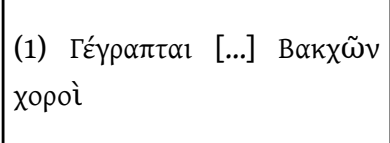 & 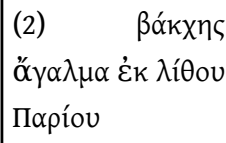 \\
\hline 1.61 ut [...] bacchantis & 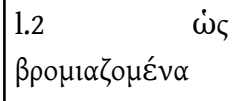 & 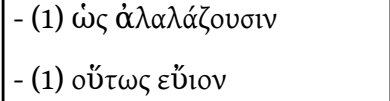 & 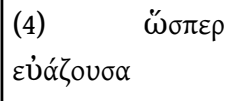 \\
\hline $\begin{array}{l}\text { - } 1.124 \text { furentem } \\
\text { - 1.254-5 alacres passim } \\
\text { lymphata mente furebant / } \\
\text { euhoe bacchantes, euhoe capita } \\
\text { inflectentes. } \\
\text { - } 1.391 \text { Thyiadas [...] euantis }\end{array}$ & 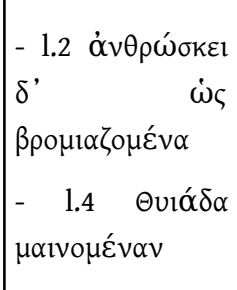 & 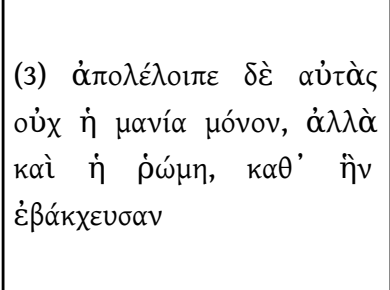 & 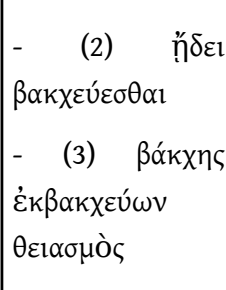 \\
\hline
\end{tabular}

The first line of the table reveals that all texts specify the artwork's object, a Bacchante, and its medium, sculpture or painting. The second line points out that all texts use a comparative introducing a present participle to render the illusion of Bacchic frenzy created by the artwork. ${ }^{27}$ The verb bacchare for instance refers at the same time to a Bacchic shout, movement and psychological state. The table's first two lines thus reveal how the texts use the illusionist topos's structuring characteristics. The third line lists similar expressions of Bacchic frenzy. In the case of Catullus, the woven Ariadne's comparison to a sculpted Bacchante turns out to be a prolepsis announcing the arrival of Bacchus and of real Bacchantes. In Callistratus, the rewriting of the topos is made clear by the explicit choice of Skopas's statue, a favored topic of epigrams. In the case of Philostratus, the rewriting of Euripides' Bacchae makes the scene so full of sound and animation that the reader can hardly decide what is actually represented on the painting.

Illusionist epigrams express the artwork's animation through the keywords ع̈ $\mu \pi v o o \varsigma$ and $\varepsilon$ $\mu \psi v \times \circ \varsigma$ ("breathing, alive," respectively from $\pi v o \eta ́$, "breath," and $\psi v \times \eta$, "life,

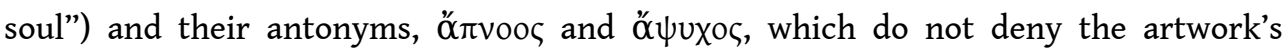
illusionism but rather produce a paradoxical variation on the topos. ${ }^{28}$ Both Philostratus and Callistratus use these keywords in the passages above: Callistratus clearly opposes

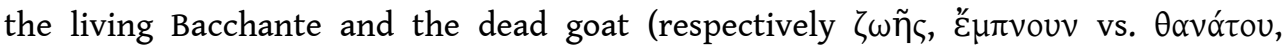
$\theta \alpha v \alpha \tau \omega \theta \varepsilon \tilde{i} \sigma \alpha v)$ as well as inanimate matter and Skopas's wonderful art ( $\dot{\alpha} \psi v ́ x o u \varsigma$ vs. $\tau \grave{\alpha}$ $\theta \alpha u ́ \mu \alpha \tau \alpha)$. Euripides's tale enables Philostratus to describe Agave and her companions

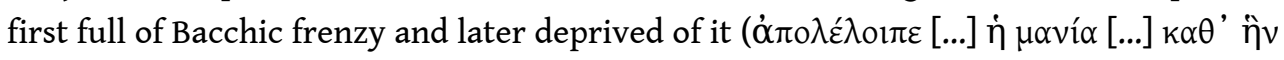
$\dot{\varepsilon} \beta \alpha \kappa_{k \chi \varepsilon}{ }^{\prime} \sigma \alpha v$, "the madness they possessed in the Bacchic revel has left them"), first

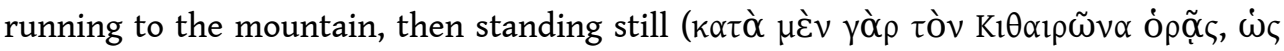

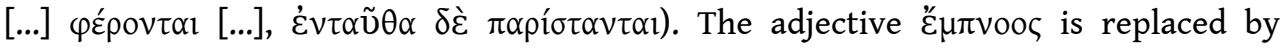

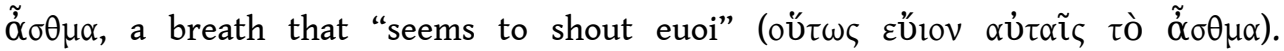
Philostratus does use $\varepsilon \check{\mu} \mu \pi v o o \varsigma$ as an expression of illusionist art elsewhere, ${ }^{29}$ for 
instance to describe a painting of Perseus where it is combined with $\tilde{\alpha} \sigma \theta \mu \alpha$ (Imagines 1.29.4):

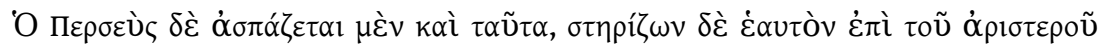

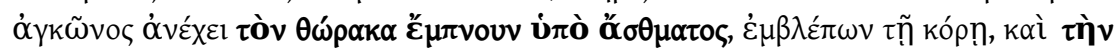

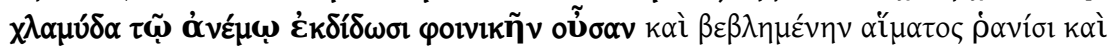

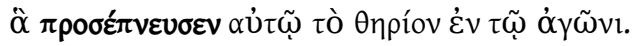

Perseus welcomes their gifts and, supporting himself on his left elbow, he lifts his chest, filled with breath through panting, and keeps his gaze upon the maiden, and lets the wind blow out his chlamys, which is purple and spattered with drops of blood and with the flecks which the creature breathed upon it in the struggle.

Bacchantes are thus represented both by Callistratus and Philostratus as particularly illusionist, in conformity with their noisy and agitated behavior. However, Philostratus's Ariadne, far from maenadic, is overwhelmingly still and silent.

\section{Listening to a Speaking Ariadne or Watching an Allegory of Sleep?}

While the Catullan Ariadne roams Dia in search of Theseus and laments his treacherous departure before Bacchus finally arrives with his thiasus, the Philostratean Ariadne from Imagines 1.15 is found asleep by the god. ${ }^{30}$ Is Philostratus simply following the most frequent iconography of Ariadne ${ }^{31}$ or could he be actively correcting Catullus's model?

\subsection{An ekphrasis characterized by negations and preteritions}

Out of the 300 words that constitute Philostratus's ekphrasis of Ariadne, no less than 11 clauses are negative ${ }^{32}$. Let us consider the first two sentences:

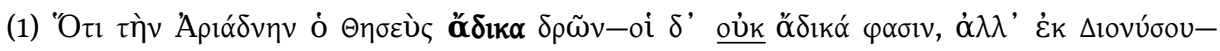

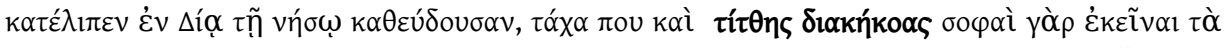

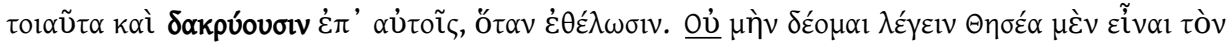

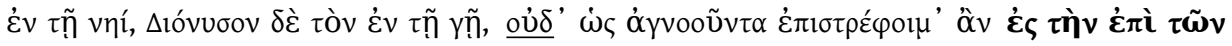

That Theseus treated Ariadne unjustly-though some say not with unjust intent, but under the compulsion of Dionysus-when he abandoned her while asleep on the island of Dia, you must have heard from your nurse; for those women are skilled in telling such tales and they weep over them whenever they will. I do not need to say that it is Theseus you see there on the ship and Dionysus yonder on the land, nor will I assume you to be ignorant and call your attention to the woman on the rocks, lying there in gentle slumber.

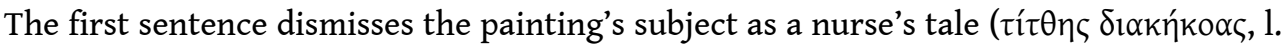
2-3) even though it seems to characterize Catullus's version. Indeed, the compassion for Ariadne as a victim of Theseus emphasized here by the term ö $\delta i \kappa \alpha$ constitutes a leitmotif of Catullus 64 through the repeated address to Theseus as perfidus 
("faithless"). Catullus also uses the expression iusta [...] multa ("a just punishment" 1 . 190) to describe what Theseus's desertion deserves. By contrast, most Athenian versions of Ariadne's myth, both literary and visual, make Theseus leave her to obey Athena: far from unjust, his action is seen as pious ${ }^{33}$. Second, the Catullan Ariadne is described crying when she laments her fate, ${ }^{34}$ just as the Philostratean nurses are said

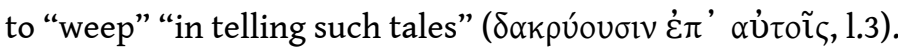

Philostratus fills the the second sentence with preteritions: there is no point in naming

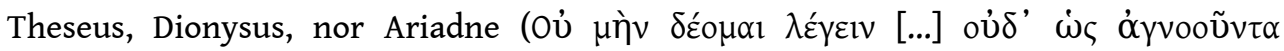
$\dot{\varepsilon} \pi \imath \sigma \tau \rho \varepsilon \varphi \circ \iota \mu$ 1.4-5). In the third sentence, he refuses to praise the painter for an easy

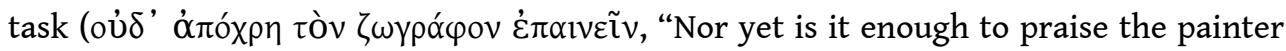
for things for which someone else too might be praised"). It is easy to paint beautiful characters, especially if they have traditional attributes that constitute an iconographic code, such as Dionysus.

\subsection{Dionysus's paradoxical portrayal: a correction or an imitation of Catullus?}

Philostratus lists typical attributes of Dionysus before stating that this portrait does not include them, because "the painter has characterized [this Dionysus] by love alone"

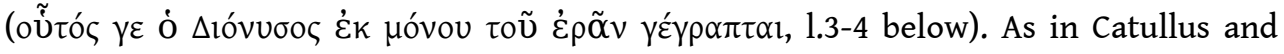
ekphrastic epigrams, the point is to show how visual arts can represent emotions and not only appearances.

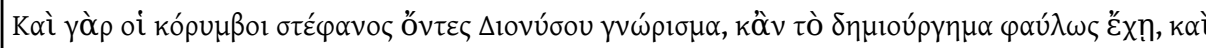

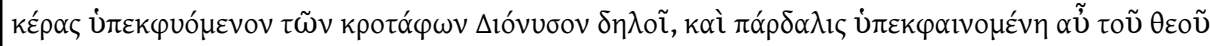

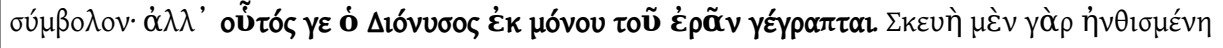

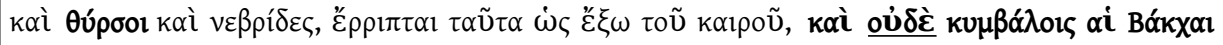

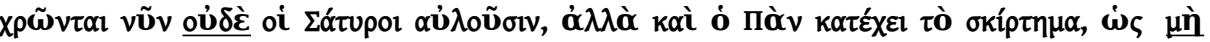

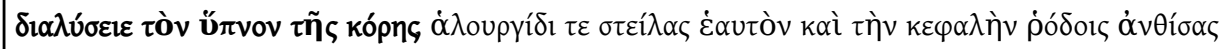

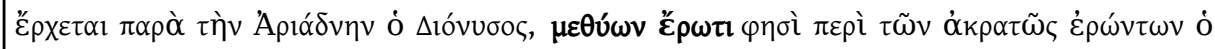
Tท́ıь.

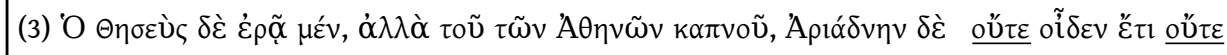

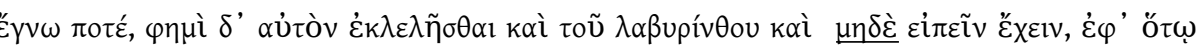

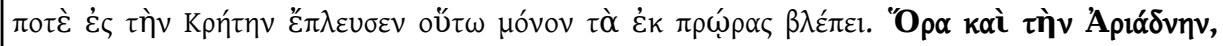

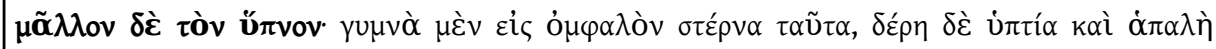

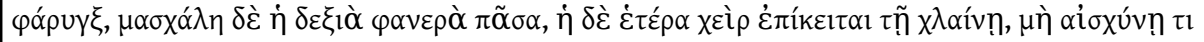

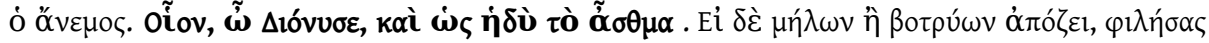

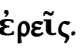


For instance, the ivy clusters forming a crown are the clear mark of Dionysus, even if the workmanship is poor; and a horn just springing from the temples reveals Dionysus, and a leopard, though but just visible, is a symbol of the god; but this Dionysus the painter has characterized by love alone. Flowered garments and thyrsi and fawn-skins have been cast aside as out of place for the moment, and the Bacchantes are not clashing their cymbals now, nor are the Satyrs playing the flute, nay, even Pan checks his wild dance that he may not disturb the maiden's sleep. Having arrayed himself in fine purple and wreathed his head with roses, Dionysus comes to the side of Ariadne, "drunk with love" as the Teian poet says of those who are overmastered by love. As for Theseus, he is indeed in love, but with the smoke rising from Athens, and he no longer knows Ariadne, and never knew her, and I am sure that he has even forgotten the labyrinth and could not tell on what possible errand he sailed to Crete, so singly is his gaze fixed on what lies ahead of his prow. And look at Ariadne, or rather at her sleep; for her bosom is bare to the waist, and her neck is bent back and her delicate throat, and all her right armpit is visible, but the left hand rests on her mantle that a gust of wind may not expose her. How fair a sight, Dionysus, and how sweet her breath! Whether its fragrance is of apples or of grapes, you can tell after you have kissed her!

However, even if anything picturesque seems to be chased out of the door, it soon comes back through the window. The next sentence starts by rejecting other attributes of Dionysus but reintroduces Bacchantes, Satyrs and Pan -with an important condition: they are to remain silent and motionless. On the contrary, the Catullan thiasus stands out by its extreme rowdiness. The three elements rejected by Philostratus are present in Catullus, i.e. the cymbals, the flute and Bacchic dancing, as revealed by this table:

\begin{tabular}{|c|c|c|}
\hline $\begin{array}{l}\text { Elements rejected } \\
\text { by Philostratus }\end{array}$ & Elements selected by Catullus & $\begin{array}{l}\text { Elements selected by } \\
\text { Philostratus }\end{array}$ \\
\hline & Dionysus's love (incensus amore 1.253 ) & 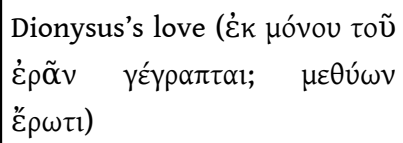 \\
\hline \multirow[t]{4}{*}{ Thyrsi ( $\theta u ́ p \sigma o l)$} & Thyrsi (quatiebant thyrsos 1.256 ) & \\
\hline & $\begin{array}{l}\text { Noisy cymbals } \\
\text { (tereti tenuis tinnitus aere ciebant } 1.262 \text { ) }\end{array}$ & 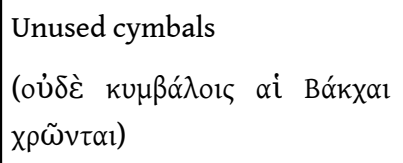 \\
\hline & $\begin{array}{l}\text { Satyrs and Silens playing the flute } \\
\text { (thiaso Satyrorum et Nysigenis Silenis 1.252; } \\
\text { barbaraque horribili stridebat tibia cantu 1.264) }\end{array}$ & 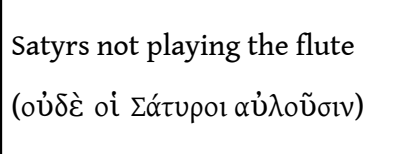 \\
\hline & $\begin{array}{l}\text { Dancing thiasus alacres [...] euhoe capita } \\
\text { inflectentes } 1.254-5\end{array}$ & 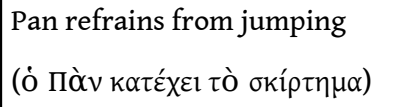 \\
\hline 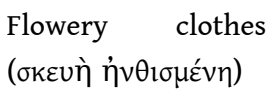 & $\begin{array}{l}\text { Flowery Dionysus } \\
\text { (florens } 1.251)\end{array}$ & 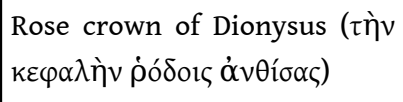 \\
\hline
\end{tabular}


Philostratus thus raises two major issues. First, he points to the composition's verisimilitude: how could Ariadne be asleep with all that noise ${ }^{35}$ Catullus had emphasized the silence reigning on the apparently deserted island before Dionysus's arrival, but not commented on the effects of the noisy thiasus on Ariadne. Second, Philostratus questions the capacity for a painting to represent sounds and movements. Indeed, Bacchantes and Satyrs possess musical instruments but do not play them because painting cannot produce sounds. Similarly, Pan seems to refrain from jumping, frozen in a leap that is only suggested. Philostratus thus illustrates the illusionist topos's variant that emphasizes visual representations' absence of life. In so doing, he seems to correct Catullus, both at a narrative and at an ekphrastic level.

In that sense, when Philostratus explicitly cites Anacreon ('“drunk with love' as the Teian poet says," $\mu \varepsilon \theta u ́ \omega v$ ع́ $\rho \omega \tau$ surreptitiously correcting Catullus instead? Let us compare the relevant passages:

-Anacreon, Loeb, fr. 376 Hephaestion, On Poems, ed. and transl. D. Campbell, 1982:

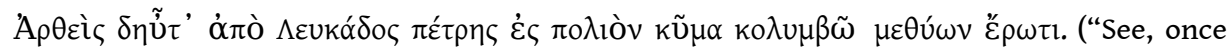
again I climb up and dive from the Leucadian cliff into the grey waves, drunk with love.")

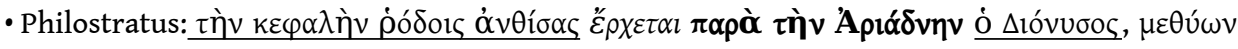
है $\rho \omega \tau 1$

- Catullus: florens uolitabat Iacchus / [...] te quaerens, Ariadna, tuoque incensus amore. ("Flowering Iacchus was wandering, [...] seeking you, Ariadne, and burning with love for you")

Anacreon is not describing Dionysus in this passage, whereas Catullus's sentence is located precisely at the same narrative moment and applied to the same pictorial element. Both in Philostratus's and Catullus's passages, the line describes a flowering Dionysus approaching Ariadne. Philostratus could thus be using Anacreon's quote to correct Catullus since drunkenness ( $\mu \varepsilon \theta u v \omega v$ ) is more appropriate than fire (incensus) to characterize the wine god's love. Interestingly, Catullus does use a similar image in poem 45 where loving eyes are labelled ebrii ocelli ("drunk eyes" 1.11). Philostratus also brings Dionysus and Ariadne closer by juxtaposing their names in that line, whereas in Catullus they are physically separated by the thiasus, and metrically by one line and a half of poetry. The unreliability of Philostratus's quotations has been pointed out by Carolyn MacDonald ${ }^{36}$ : in Imagines 1.8, Philostratus compares the representation of Poseidon to the Iliad (13.23ff), referring to Homer by name (Imag. 1.8.1), although the painting is actually completely different from Homer's representation of the god. On the other hand, the ekphrasis of 1.18 is closely inspired by Euripides but his name is not mentioned. MacDonald further shows that behind this elaborate rewriting of the Bacchae, Philostratus might add suprepticioulsy some allusions to Ovid since e.g. the metamorphosis of Cadmus and Harmonia described in 1.18.4 was not treated by Euripides but by Ovid, Met. 4.574-5. Considering Philostratus's appeal to the reader's experience in intertextual games, it would not be surprising that the naming of Anacreon actually disguised a correction of Catullus. A further argument to explain why Catullus would be replaced by Anacreon would be the idea that Catullus is a Roman Anacreon, as implied by the Gellius anecdote mentioned earlier (NA 19.9). As Jolowicz (2021: 32) says, "one way of understanding the lack of obvious markers to and, more importantly, citation of Latin poetry thus relates to the identity politics of the period, specifically the stereotype according to which Romans are the brokers of power and 
Greeks the brokers of culture [...], of which literature is a predominant constituent. This was a stereotype that both parties had a stake in preserving".

\subsection{Ariadne as a paragon of passivity}

We have shown how Catullus animates Ariadne's figure from the very first lines of the ekphrasis. On the contrary, her first description by Philostratus sets the tone: she is

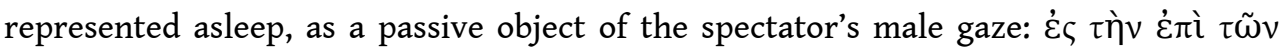

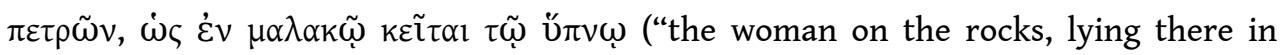
gentle slumber," Imagines 1.15.1). Ariadne is not named, she is the object of $\mu \alpha \lambda \alpha \kappa o ̀ \varsigma$ Ǔ $\pi v o s$, a formulaic expression used by Homer and medical texts alike but that is given fresh meaning here. Indeed, the word $\mu \alpha \lambda \alpha$ kó means "soft to the touch, delicate" and participates to the erotic dimension of Ariadne's description which is further developed by the adjective $\dot{\alpha} \pi \alpha \lambda$ ć ("soft to the touch, tender") at the end of the ekphrasis. Let us compare this passage to Catullus's:

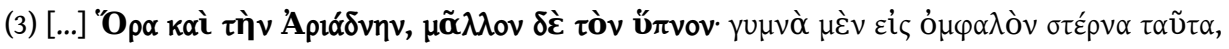

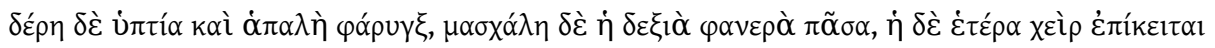

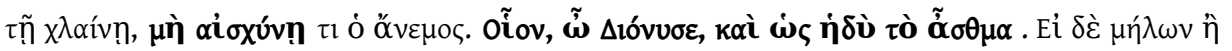
4

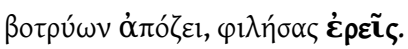

Philostrates, Imagines 1.15.3.

And look at Ariadne, or rather at her sleep; for her bosom is bare to the waist, and her neck is bent back and her delicate throat, and all her right armpit is visible, but the left hand rests on her mantle that a gust of wind may not expose her. How fair a sight, Dionysus, and how sweet her breath! Whether its fragrance is of apples or of grapes, you can tell after you have kissed her!

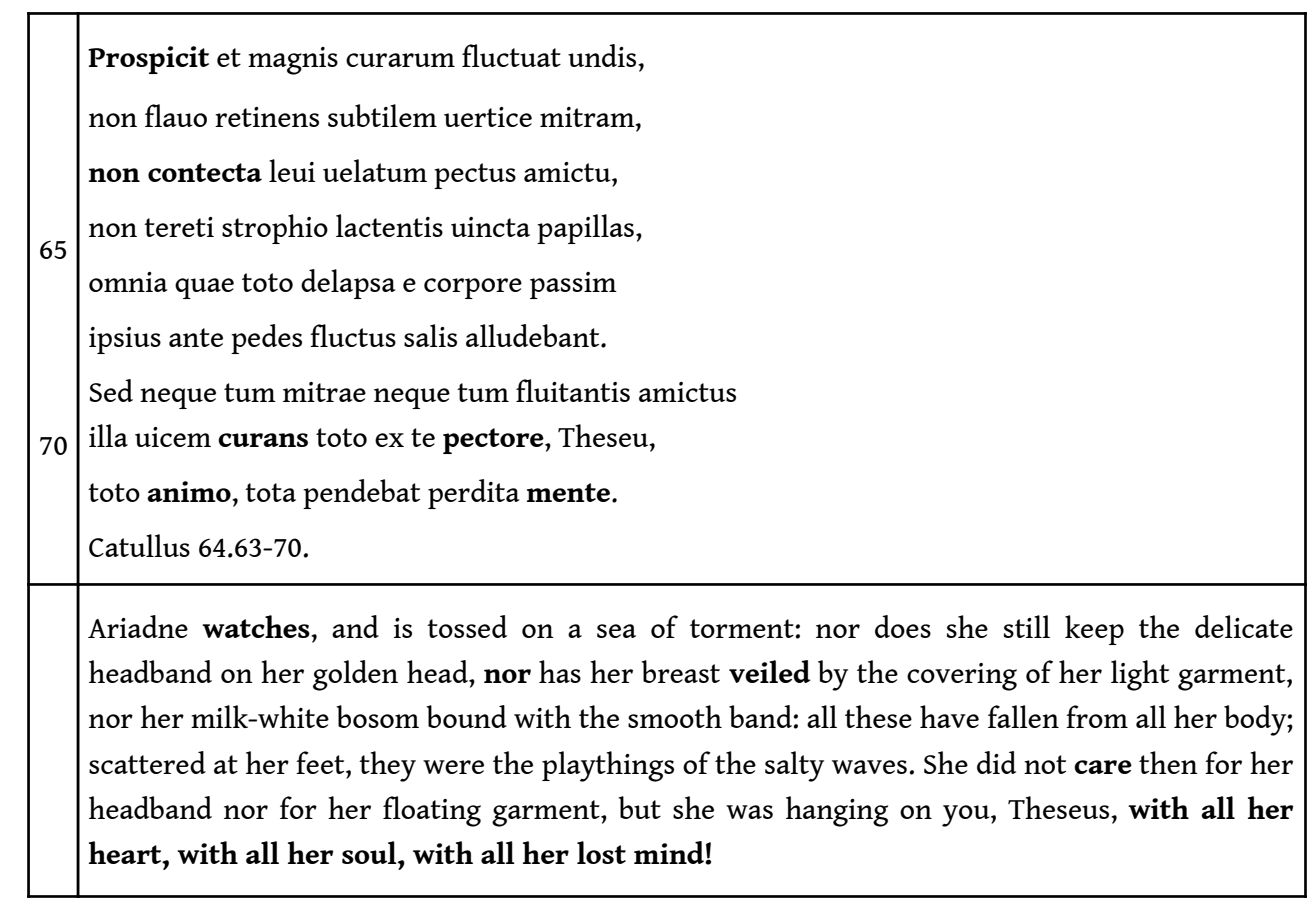




\begin{tabular}{|l|l|}
\hline Philostratus & Catullus \\
\hline Ariadne, object of gaze (l.1, 'O $\rho \alpha)$ & Ariadne, gazing subject (1.62, prospicit) \\
\hline $\begin{array}{l}\text { Eroticized Ariadne (l.1-3): half-naked, showing her } \\
\text { breast and armpit, possibly further unveiled by the } \\
\text { wind }\end{array}$ & $\begin{array}{l}\text { Eroticized Ariadne (1.63-68): half-naked and } \\
\text { unveiling (less erotic than in Philostratus } \\
\text { though) }\end{array}$ \\
\hline Ariadne asleep, lying down (l. 1-3) & Ariadne awake, most likely standing (1.62-70) \\
\hline Complicit address to the lover (l.4) & Accusatory address to the lover (1.69-70) \\
\hline Passive interiority (l.1-4) & Active interiority (1.62; 1.69-70) \\
\hline
\end{tabular}

Even though the Catullan Ariadne is eroticized, the reader adopts her viewpoint and is plunged in her interiority which is emphasized by the ternary rhythm and alliterations in [ $\mathrm{t}$ ] of 1.69-70 (toto ex te pectore, Theseu, / toto animo, tota pendebat perdita mente, the three words pectus, animus and mens refer to the siege of her thoughts and emotions). On the other hand, the Philostratean Ariadne is never more than the object of the male gaze, since the spectator of the painting identifies to Dionysus. The phrase "O $\rho \alpha$ k $\alpha \grave{i}$

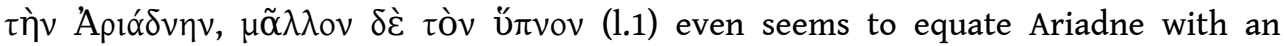
allegory of sleep, a passive state par excellence. Ariadne has no personality, even her breath ( $\tilde{\alpha} \sigma \theta \mu \alpha 1.4)$ is not seen as a proof of movement of sound but only praised for its perfume.

While the Catullan heroine, in spite of her eroticism, emancipates herself from the spectator's reifying gaze by voicing an entire soliloquy that precisely denounces the injustice of masculine desire, in Philostratus only Dionysus is allowed a few words that further objectify Ariadne: "Whether [the] fragrance [of Ariadne's breath] is of apples or

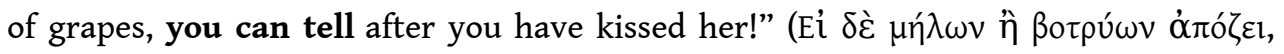

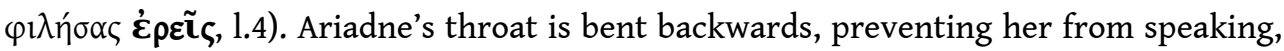
and the adjective that describes this pose, Ǔ $\pi \tau 10 \varsigma$ 1.2, can also qualify "flat" and "dull" language. Thus, the Philostratean heroine is reduced by her sleep to the status of a beautiful object whose awakening would be too dangerous to risk, as expressed in this

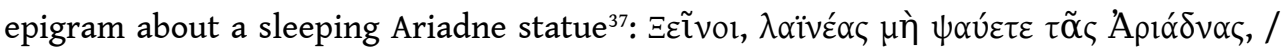

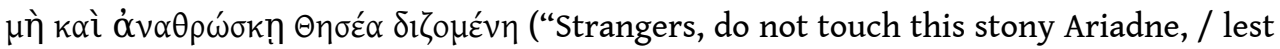
she jumps off after Theseus").

To conclude, interpreting the Philostratean Ariadne as a correction of Catullus 64 seems fruitful for several reasons. If we consider the Imagines as a whole, what justifies the lesser illusionism of 1.15? The ekphrasis is not completely devoid of illusionism, but it is quite minimal considering the topic: Ariadne's lament, the tumultuous thiasus, and Dionysus's desire could all have been rich in sound and movement. Even if we compare this ekphrasis to the extent visual artworks on the subject, the latter appears more picturesque: the thiasus is generally more animated, air lifts Dionysus's veils, the god seems to speak, an Eros unveils Ariadne, etc. Considering 1.15 only, why start by blaming Theseus's injustice but completely silence Ariadne's viewpoint? 
For text and image studies, Catullus seems to offer to Philostratus a fascinating precedent vis à vis the incorporation into longer literary genres of epigrammatic motifs, especially the illusionist topos which activates various concepts from art criticism. meaning to our hypothesis, namely that Philostratus silences the Catullan Ariadne, so fecund in Roman verses? Far from ignoring Latin literature, Philostratus would here be staging the Atticist's feigned refusal to dialogue with it, in order to perpetuate the stereotype of the superiority of Greek culture over Romanity. Just as many modern critics, Philostratus could be critical of Ariadne's lengthy monologue that stems from an ekphrasis; he could criticize the lack of verisimilitude of the presence of such a rowdy thiasus on a seemingly deserted island; finally, he could disapprove of the chosen epithet for Dionysus, a wine god who should be drunk on love and not burnt by love. Philostratus would thus take the role of a literary critic of Catullus, just as he has been shown to critique Homer. The Anacreon quotation would prove his attempt to give the illusion of an unchanged Greek world, an attempt that was so successful that it is generally considered to constitute the truth of Atticist Greek imperial literature.

\section{BIBLIOGRAPHY}

Biraud, Michèle, et Arnaud Zucker. The Letters of Alciphron: A Unified Literary Work? Vol. 424.

Mnemosyne, Supplements, Late Antique Literature. Boston: Brill, 2018.

Bowie, Ewen, and Jaś Elsner. Philostratus. Greek Culture in the Roman World. Cambridge, UK; New York: Cambridge University Press, 2009.

Bozia, Eleni. Lucian and His Roman Voices: Cultural Exchanges and Conflicts in the Late Roman Empire. Routledge Monographs in Classical Studies. New York; London: Routledge, 2015.

Byrne, Shannon N., and Edmund P. Cueva, eds. A Companion to the Ancient Novel. Blackwell Companions to the Ancient World. Literature and Culture. Chichester, West Sussex: Wiley Blackwell, 2014.

Campbell, David A., ed. and transl. Greek Lyric, v. 2. Loeb Classical Library 143. Cambridge, Mass.; London: Harvard University Press; W. Heinemann, 1982.

Cornish, Francis W., J. P. Postgate, J. W. Mackail, eds. and transl. Catullus, Tibullus, Pervigilium Veneris. second ed., rev. by G.P. Goold. Loeb Classical Library 6. Cambridge, Mass.: Harvard University Press, 1988.

Courtney, E. Musa Lapidaria: A Selection of Latin Verse Inscriptions. American Classical Studies; No. 36. Atlanta, Ga.: Scholars Press, 1995.

Doroszewski, Filip, et Katarzyna Jazdzewska. Nonnus of Panopolis in Context III: Old Questions and New Perspectives. Mnemosyne, Bibliotheca Classica Batava. Supplementum 438. Leiden; Boston: Brill, 2021.

Dufallo, Basil. The Captor's Image: Greek Culture in Roman Ecphrasis. Oxford University Press, 2013. 
Fairbanks, Arthur, ed. and transl. Philostratus, Imagines; Callistratus, Descriptions. Loeb Classical Library. London: New York: W. Heinemann; Putnam, 1931.

Fuà, Oscar. “L'idea dell'opera d'arte 'vivente' e la bucula di Mirone nell'epigramma greco e latino." Rivista Di Cultura Classica e Medioevale, 15.1973, 1973, 49-55.

Gaisser, Julia H. "Catullus (1), Gaius Valerius." In The Oxford Classical Dictionary. Oxford University Press, 2012. Date accessed 31 May 2021. https://www-oxfordreference-com.ezpprod1.hul.harvard.edu/view/10.1093/acref/9780199545568.001.0001/acref-9780199545568e-1443.

Gallo, Anna. "Le Pitture Rappresentanti Arianna Abbandonata in Ambiente Pompeiano." Rivista Di Studi Pompeiani 2 (1988): 57-80.

Goldhill, Simon, and Robin Osborne. Art and Text in Ancient Greek Culture. Cambridge \& New York: Cambridge University Pr., 1994.

Haynes, Denys Eyre Lankester. The Technique of Greek Bronze Statuary. Mainz am Rhein: Pvon Zabern, 1992.

Hodkinson, Owen. Brief Encounters: Studies in the Letters of Alciphron, Aelian, and Philostratus." Doctorate defended at Oxford University, Oxford, 2009.

Hose, Martin. “Die Römische Liebeselegie Und Die Griechische Literatur.” Philologus 138, no. 1 (1994): 67-82.

Iff-Noël, Flora. Ariane, vision parlante ? L'ekphrasis illusionniste chez Catulle et les épigrammatistes hellénistique. Thèse soutenue à Sorbonne Université, Paris, 2019.

Iff-Noël, Flora. "Le Topos hellénistique de l'illusionnisme de l'art : mimésis et paragone." In Le Mythe de l'art antique, CNRS Éditions, 213-27. Paris, 2018.

Jolowicz, Daniel. Latin Poetry in the Ancient Greek Novels. Oxford Classical Monographs. Oxford, New York: Oxford University Press, 2021.

Jolowicz, Daniel Arnold. Latin Poetry and the Idea of Rome in the Greek Novel. Doctorate defended at the University of Oxford, Oxford, 2015. https://ora.ox.ac.uk/objects/uuid:00441253-6764-476fa599-311f28396e94.

MacDonald, Carolyn. "Echoes of Ovid? Memories of the Metamorphoses in Philostratus' Imagines," forthcoming.

McNally, Sheila. "Ariadne and Others. Images of Sleep in Greek and Early Roman Art." Classical Antiquity 4 (1985): 152-92.

Prioux, Évelyne. "L'ecphrasis dans l'epyllion." Aitia. Regards sur la culture hellénistique au XXIe siècle, no. 6 (2016).

Rochette, Bruno. Le Latin dans le monde grec : recherches sur la diffusion de la langue et des lettres latines dans les provinces hellénophones de l'Empire romain. Collection Latomus; v. 233. Bruxelles: Latomus, 1997.

Rosenmeyer, Patricia A. Ancient Epistolary Fictions: The Letter in Greek Literature. Cambridge; New York: Cambridge University Press, 2001.

Rouveret, A. Histoire et imaginaire de la peinture ancienne : $V^{e}$ siècle av. J.-C.-Ir siècle ap. J.-C. Bibliothèque des écoles françaises d'Athènes et de Rome ; fasc. 274. Roma: Ecole française de Rome, 1989. 
Squire, Michael. “Making Myron's Cow Moo?: Ecphrastic Epigram and the Poetics of Simulation.” American Journal of Philology 131, no. 4 (2010): 589-634.

Torres-Guerra, José B. Vtroqve sermone nostro: bilingüismo social y literario en el Imperio de Roma. Colección Mundo antiguo; no. 14. Pamplona: Eunsa, 2011.

Webb, Ruth H. “Les Images de Philostrate : une narration éclatée." In La trame et le tableau : poétiques et rhétoriques du récit et de la description dans l'Antiquité grecque et latine (actes du colloque des 21-23 octobre 2010), edited by Michel Briand, 19-33. La Licorne 101. Rennes: Presses universitaires de Rennes, 2012.

Whitmarsh, Tim. Local Knowledge and Microidentities in the Imperial Greek World. Greek Culture in the Roman World. Cambridge: University Press, 2010.

Wiseman, T. P. Catullus and His World: A Reappraisal. Cambridge; New York: Cambridge University Press, 1985.

Wolf, Claudia Marie. Die Schlafende Ariadne Im Vatikan : Ein Hellenistischer Statuentypus Und Seine Rezeption. Hamburg: Kovac, 2002.

\section{NOTES}

1. See Fuà, 1973; Iff-Noël, 2018; Iff-Noël, 2019.

2. Translations of Philostratus and Callistratus are by A. Fairbanks, 1931; those of Catullus by F. W. Cornish, revised by G. P. Goold, 1988; unless otherwise specified, all other translations are mine.

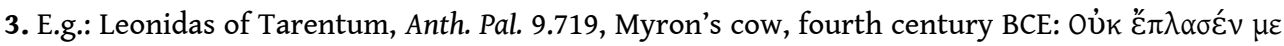

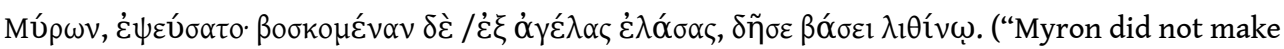
me; he lied: while I was grazing / he drove me from the herd and attached me to a stone base").

4. Webb, 2012: 29.

5. Newby in Bowie and Elsner, 2009: 338-339. Philostratus even writes explicitly about the hunter painting: "I was deluded by the painting into thinking that the figures were not painted but were

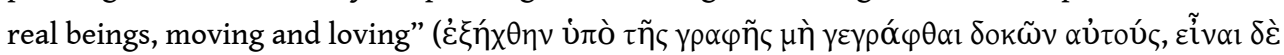

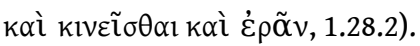

6. Iff-Noël, 2019.

7. The fact that Philostratus wrote in Greek should not make us question the existence of a Roman readership for his works: the Roman elite read Greek fluently, at least since the $1^{\text {st }}$ cent. BCE; moreover Philostratus lived in Rome, at the imperial court, and therefore wrote at least partially for Romans.

8. Rochette, 1997: 257-326.

9. Jolowicz (2021: 15) writes that "careers in Rome require a knowledge of Latin. Valerius Maximus reports that Romans respond to Greeks only in Latin (2.2.2 - 3), and Suetonius transmits an anecdote in which Claudius even deprived a Greek of his citizenship for his inability to speak the language (Claud.16.2; cf. Dio 60.17.3 - 4)". The Greeks became increasingly integrated into the Roman Empire, especially after the Constitutio Antoniniana issued by Caracalla in 212 which made every free man in the empire a Roman citizen (see Jolowicz, 2021: 3). Jolowicz (2021: 14) "establish[es] some further contexts in which Greeks may have encountered Latin literature (especially poetry), including education, the agonistic circuit, and libraries; in doing so [he] presses on evidence that has never been pressed in this connection (much of it epigraphic and archaeological). [His] reading of the evidence in these sections gives a deliberately 
cumulative and maximal view of the spread and depth of Greek appreciation for Latin literature, which will thus offer a counterweight to the traditionally pessimistic approach to this question".

10. See also Torres-Guerra, 2011.

11. Bryson in Goldhill and Osborne, 1994: 255-283.

12. Gaisser, 2012.

13. Apul. Apol. 6; 11; 20; Gell. NA 6.20.6; 7.16.2; 19.9; Auson. Ecl.1.1-3; Praefationes 4.1-3; Servius Verg. Aen. 4.409; 12.587; Jer. Chron. 173.2; 180.3; August. De Musica 5.5; 5.11; 5.16; Macrob. Sat. 2.1.8; 6.1.42; 6.1.41; Mart. Cap. 3.229. Less famous authors are Pomponius Porphyrion (second-century African, Hor. Serm. 2.3.299), Terentius or Terentianus Maurus (a third-century grammarian from Mauritania, De Metris 2560-64; 2276-77; 2899-2900), Censorinus (a third-century Italian grammarian; CGL 6.614.17-19; 6.612.17-18), Atilius Fortunatianus, fourth century, Africa?, CGL 6.293.6-8; 6.298.21-23), Flavius Sosipater Charisius (a fourth-century Roman grammarian, CGL 1.97.10-13; 1.133.25-134.1; 1.252.27-29), Diomedes (a fourth-century grammarian, CGL 1.344), Aelius Festus Aphthonius (a fourth or fifth-century Italian grammarian, CGL 6.125.2-6; 6.134.2-4; $6.136 .19-20 ; 6.148 .19-24 ; 6.154 .23-24)$. At the turn of the first and second century, we can also mention Pliny the Younger who said he wrote hendecasyllables in the manner of Catullus, and asserts that the now unknown poets Pompeius Saturninus and Sentius Augurinus also did (Epist. $1.16 .5 ; 4.27 .1-4 ; 7.4)$.

14. CIL 14.3565.47-51 = CLE 1504.47-51 = Courtney 1995 155.47-51; CIL 14.3565.8-11 = CLE 1504.8-11 = Courtney 1995 155.8-11; CIL 13.488 = CLE 1512 = Courtney 1995 204; CIL 14.3565.13-17 = CLE 1504.13-17 = Courtney 1995 155.13-17.

15. Moreschini in Byrne and Cueva, 2014: 517-518.

16. Hallett and Hindermann in Byrne and Cueva, 2014: 300-316.

17. Jolowicz, 2015: 13; see also Jolowicz, 2021: 19-20.

18. Schoess in Biraud and Zucker, 2018: 89-108. Schoess (99-101) notes that Glycera compares Menander and herself to Bacchus and Ariadne, and asserts that Menander will not abandon her as Theseus did Ariadne. Schoess shows how the allusions to Catullus 64 and Ovid's $10^{\text {th }}$ Heroid enrich the text and argues that the reader would have recognized them.

19. Rosenmeyer (2001) also discusses Ovidian influences on Alciphron.

20. Gleason in Whitmarsh, 2010: 135-142

21. Ars Am. 1.525-564; Fast. 3.459-516; Her. 10; Met. 8.169-182.

22. Duffalo, 2013: 249.

23. On this point see also MacDonald, forthcoming. I thank her for sharing a draft of her article with me.

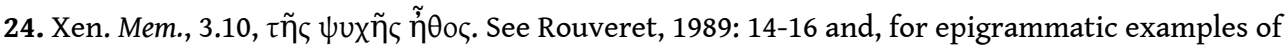
the debate Squire, 2010: 606.

25. On the techniques of eye inlays, see Haynes, 1992: 106-107. We have preserved a secondcentury BCE Greek bronze bust of Ariadne whose eyes are made of marble with hollowed pupils (Bardo National Museum, inv. F 108, LIMC, "Dionysus" 190).

26. See Prioux, 2016: $\S 18$. There is a first-century CE Roman copy of the Greek Bacchante statue created by Scopas in the fourth century BCE, at the Dresden Albertinum.

27. Yet the comparison has a slightly different meaning in Catullus: it is not a statue that seems to revel like a Bacchante but the woven Ariadne who seems a sculpted Bacchante.

28. See Iff-Noël, 2018 and 2019.

29. E.g. Narcissus 1.23, Perseus 1.29, Hippolytus 2.2, the sea 2.17, Hercules and the Pygmies, 2.22 .

30. In both texts, the island is named Dia (probably following Callimachus, fr. 601 Pfeiffer), although it is much more commonly referred to as Naxos.

31. The forsaken Ariadne is much more often represented asleep than awake in visual arts, see LIMC, 1981-2009: 1052-1070; McNally, 1985; Gallo, 1988; Wolf, 2002. The few examples where she is awake are mostly from Pompeii, but even there she is sitting down at best, never standing up 
(except maybe in the wall-painting from the House of Alexander's wedding, VI.17.42, inv. 41658, Pompeii). See Iff-Noël, 2019.

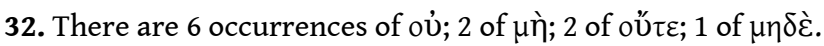

33. This could be a window-reference to Callimachus's treatment of the Demophoon and Phyllis

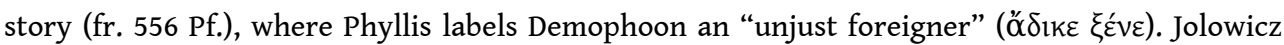
(2021: 194-197) points out that male perfidy in Achilles Tatius alludes to Catullus 64 and the Aeneid 4 more than to Greek predecessors.

34. Catul. 64.131-132: atque haec extremis maestam dixisse querellis, / frigidulos udo singultus ore cientem ("this is what she said sadly in her last laments, uttering icy sobs with a tearful face").

35. That is stated explicitly: "even Pan checks his wild dance that he may not disturb the

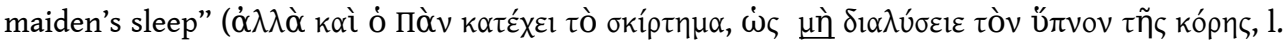
6-7).

36. MacDonald, forthcoming.

37. Anth. Plan. 146, an anonymous epigram of uncertain date.

\section{ABSTRACTS}

Recently, suggestions of Latin influences on imperial Greek literature have been met with increasing acceptance. What was the place of Catullus from the second to the fourth century CE? After a short overview of his mentions and quotations, we will devote a case study to the comparison of the ekphrasis of Ariadne in Catullus 64 and that in Philostratus's Imagines 1.15, as well as the ekphrasis of Bacchantes in Catullus 64, Philostratus's Imagines 1.18 and Callistratus's Ekphraseis 2. Would it be possible to read the surprising lack of illusionism in Philostratus's Ariadne as a correction of Catullus's extraordinarily illusionistic Ariadne? Could the Atticist Philostratus be staging the Atticist's feigned rejection of Latin literature by silencing the Catullan Ariadne and by making her Latin love song disappear?

\section{INDEX}

Keywords: Catullus, Philostratus, Callistratus, Second Sophistic, Atticism, Hellenistic epigram, intertextuality, text and image studies, ekphrasis, bilingualism, biculturalism, illusionism, Ariadne, Bacchantes, Dionysus, Skopas, male gaze

\section{AUTHOR}

\section{FLORA IFF-NOËL}

University of Florida 